\title{
The Privacy Aspects in the Malay Dwelling
}

\author{
Noorul Huda Mohd Razali, Anuar Talib \\ Faculty of Architecture, Planning and Surveying, \\ Universiti Teknologi MARA, Malaysia \\ nhuda.mrazali@gmail.com
}

\begin{abstract}
The Malay dwelling (MD) in Melaka demonstrated the Malay cultural norms, religious beliefs and the basic requirements of privacy in Islam. Privacy needs of the family members and the non-mahram visitor is determinant for designing the space planning in MD. Different types of dwelling size were selected in order to investigate the concept of privacy. Research methodology was designed on occupant observation, layout plan measurement and in-depth interviews. The results affect the privacy provisions and behaviors of MD occupants. Moreover, these findings assist to produce new design recommendations of layout plans, to achieve the privacy level from Islamic perspective.

Keywords: Privacy; Malay dwelling; floor space planning; Islamic perspectives of privacy

eISSN 2398-4295 @ 2018. The Authors. Published for AMER ABRA cE-Bs by e-International Publishing House, Ltd., UK. This is an open-access article under the CC BY-NC-ND license (http://creativecommons.org/licenses/bync-nd/4.0/). Peer-review under responsibility of AMER (Association of Malaysian Environment-Behaviour Researchers), ABRA (Association of Behavioural Researchers on Asians) and CE-Bs (Centre for EnvironmentBehaviour Studies), Faculty of Architecture, Planning \& Surveying, Universiti Teknologi MARA, Malaysia.

http://dx.doi.org/10.21834/ajbes.v3i11.111
\end{abstract}




\subsection{Introduction}

The relation of culture and environment plays important role in dwelling design. Different communities represent different types of culture, environment, socio-economic, religious beliefs and environmental behavior. Those elements influence the dwelling design (Rapoport, 2007), it expresses the cultural identity of the community and it can reveal the space behavior and space utilization (Gharaei, \& Rafieian, 2013; Rapoport, 2007). In Malaysia, the Malay dwelling (MD) this is a sample of Muslim dwelling and demonstrated the continuity of the Malay cultural norms, religious beliefs and basic requirements of privacy in Islam. The designs of the dwelling support the family needs including the activity in the space and social interaction that consistent with the people and culture (Abdul Rahim and Hashim, 2012).

The interest of privacy is discussed in variety of disciplines and has been address by few philosophers namely psychologist, sociologist and architect. All disciplines have investigated and assumed privacy as "people attempts to be open or closed, people need to avoid contact and make a distance to interact to others at certain occasion and times" (Altman \& Chemers, 1980, Altman et al 1981, Altman, 1975). Human interaction divided into three categories namely interaction with Allah, people and environment that emphasize by Islam (Mamat \& Mahamood, 2010). It is the evolving process known as privacy regulation (Altman \& Chemers, 1980).

Privacy also could be declared as a boundary for gender segregation and separation between the privacy and public life (Mortada, 2003) and restricted to stranger (Fahey, 1995). The privacy life may lead to human behavior development and moral growth (Newell, 1995; Omer, 2011).

\subsection{Literature Review}

\section{The Aspect of Privacy in the Interior of Muslim MD}

Dwelling as the safe shelter, private sanctuary, and strengthening the family relationship from the Islamic view. The dwelling functions for family education and development centered, to produce excellent Muslims for the stability of the society (Omer, 2010).

Rapoport (1969) explained the privacy need associated with sense of shame, territoriality and individual separation in space. The MD spatial organisation emphasizes the segregation between public domain and private domain, (Rapoport, 1969; Mortada, 2003; Abdul-Rahim, 2008) and the internal space division follows to the religious and cultural beliefs (Rapoport, 2007). The interior spatial organization influence the dwelling form and size to accommodate women, family, closest relative (Rapoport, 1969; Mortada, 2003) and non-mahram guests (Mortada, 2003). There are various activities that involve social interaction with both genders and Islam is very demanding towards the seclusion of women and the segregation of domain for men and women (Rapoport, 1969; Omer, 2011; Mortada, 2003).

Concept of privacy in Islam emphasize the seclusion of women, segregation between men and women, segregation spaces between privacy lives and public intercourse, hijab of the women (Omer, 2011) and architectural elements in relation to privacy where it could 
protect the security and to prevent from any intrusion of privacy life amongst Muslim women and family members (Mortada, 2003, Abdul-Rahim, 2008). Islam only allows free social interaction between an adult's men and women known as mahram, referring to a family member (Mortada, 2003).

Fig. 1 shows the privacy gradient zoning in the MD, divide into several spaces consisting public, semi-public, semi-private and private spaces which is emphasize the concept of privacy in Islam. The public space receives and entertains non-mahram guests namely neighbors, relatives and friends (Mortada, 2003) on a specific occasion and time (Altman \& Chemers, 1980; Altman et al 1981).

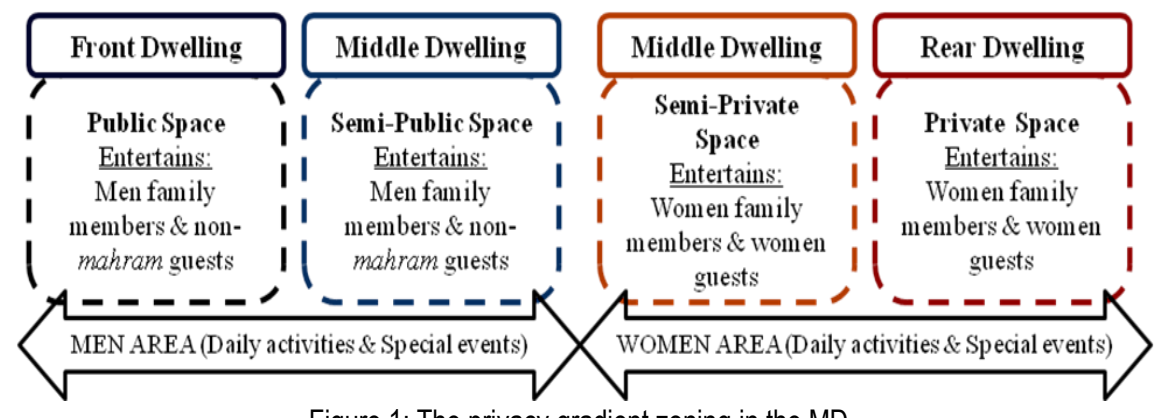

Figure 1: The privacy gradient zoning in the MD

(Source: Mortada (2003), Abdul-Rahim (2008) and Omer (2011)

Dwellings that applied Islamic law will function appropriately and could affording protection for the family privacy. A good manner or adab taught in Islam ensures the wellbeing of the Muslim community (Omer, 2011). One of the adab in the Islamic teaching is to lower their gaze during conversations and should walk far away from neighbors' dwellings. The private area is created for family members and women without interfere by non-mahram guests unwanted gaze (Mortada, 2003; Abdul-Rahim, 2008). The women domain spaces are in the family living area, kitchen and bedroom and these spaces are private areas for them (Mortada, 2003).

Mortada (2003) claim that layout plan and dwelling form as a key element in achieving a hierarchy of spaces for women privacy. The visual privacy in the dwelling protects the women occupants from the non-mahram eye as stated in the Qur'an; verses Su. 24:30 (Omer, 2010; Mortada, 2003). Muslim scholars emphasize that the architectural elements could control the visual privacy in the dwelling through the entrance doors, windows, openings and curtains (Omer, 2010; Mortada, 2003; Abdul-Rahim, 2008). The Prophet (pbuh) introduced the privacy concept shall have entrances with doors or curtains that not to reveal the interior spaces (Omer, 2011). In general, the dwelling had created wall, doors, windows and curtains to prevent the visual intrusion towards women privacy and intimacy (Rapoport, 1969; Mortada, 2003; Abdul-Rahim, 2008). 
Muslim scholars have the opinion that the entrance door should not face directly the dwelling interior (Mortada, 2003; Abdul-Rahim, 2008) because it will affect the internal privacy of the dwellers. Windows function to view the environment and neighborhood. Window must build above the eye level of the dwellers, to maintain the internal privacy (Mortada, 2003; Abdul-Rahim, 2008). Thus, Muslim dwelling contains the Islamic principles and values that are compliant to their daily activities (Omer, 2011).

\subsection{Methodology}

This research uses case study method which employs on-site observations, on-site spatial measurement of dwelling layout plans (documentation) and interviews with the occupant dwellers. The case studies sample involves two types of dwellings one is belonged to the village headman, and the other one is belonged to ordinary villagers and located at Kampong Morten. The selected dwellings represent the biggest and smallest MD with different size of layout plans. This research will be at natural setting of the MD where the information is gathered by using open-ended questions and interactively collaborating with the respondents followed to their availability and willingness to be interviewed (Creswell, 2009; 2012).

The selection of respondents was made to gather the information based on their demographic data, dwelling profile and socio-cultural needs. The in-depth interview with respondents explored the privacy provisions, religious beliefs, daily life activities and culture norms based on simple questions. On-site observation conducted to investigate the dwellers behavior and privacy needs. Respondents are from Muslim Malay families that include both gender of adults and children with different ages. The time of observation is in the morning, where the ordinary villager MD including men and women do their household activity, resting with family member and women folk do some preparation for lunch time and in the evening it is time to entertain the guest in the public space. The interview takes approximately about $45 \mathrm{~min}$, the time taken for observation of the dweller about two hours, one hour to produce a dwelling sketch, three hours for measure the whole dwelling and 45 min to capture photograph of the facade and interior. The interviews were recorded, and the results fully transcribed for analysis.

\subsection{Results and Discussions}

This research examines two types of dwellings focus on the Islamic principle of privacy and the interior architectural elements in the MD. In the fig.2, show headmen dweller and fig.3 show ordinary village dweller layout plan emphasize on zoning area, where it shows how the occupant regulate privacy within the space and daily activities. The zoning divide into public or semi-public space is a men domain (family member/ non-mahram guest) and semi-private or private spaces are a women domain (family member/ women guest).

In a year 1922, Othman Mohd Noh was appointed as headmen in Kampung Morten, Melaka. The village is named after Frederick Joseph Morten, as a land commissioner. The headmen work together with Morten and cater for the needs of the villagers. Hence, the 
dwelling was influenced from the West which can be seen on the pyramidal roof (Nasir \& Wan-Teh, 1997; 2011; Lim, 1987). This dwelling has 16 posts at the main dwelling, and allow for bigger dwelling provide spacious interior space (Al-Ahmadi, 2006).

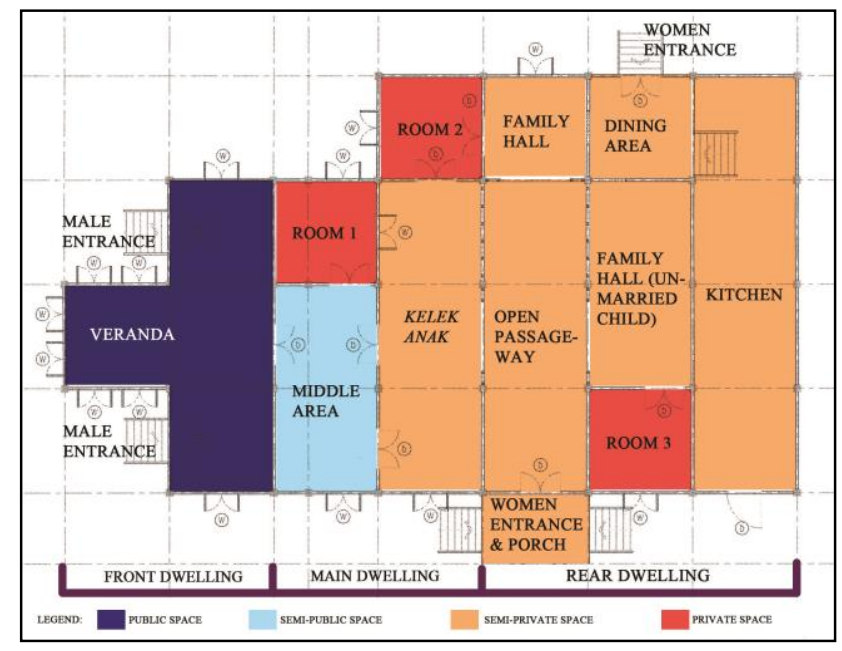

Figure 2: Layout plan of headmen MD (Source: Survey)

The total space is $2290.32 \mathrm{sq} . \mathrm{ft}$; the dwelling has wide open space to entertain the villages and to accommodate bigger families with nine children that all grew up in this dwelling. Therefore, the dwelling size and layout plan slightly larger than other dwelling in the village. The dwelling facade and interior still remain the family way of life, culture value, religious beliefs, daily activities and privacy value. Table 1 below shows the interrelation between privacy gradient zoning and daily activities.

Table 1: The MD headmen emphasize on privacy zoning, daily activities and architectural elements.

\begin{tabular}{|c|c|c|}
\hline $\begin{array}{c}\text { Privacy Gradient } \\
\text { Zoning }\end{array}$ & Daily Activities & $\begin{array}{l}\text { Application of Architectural } \\
\text { Elements } \\
\text { (to prevent gazing of guest } \\
\text { toward space) }\end{array}$ \\
\hline $\begin{array}{l}\text { Public Space } \\
\text { (Men family member } \\
\text { and non-mahram } \\
\text { guest ) } \\
\text { Men Entrance, } \\
\text { Porch and Veranda }\end{array}$ & $\begin{array}{l}\text { Main entrance for men and restricted for women. } \\
\text { Place to entertain guest, discussion area with the } \\
\text { village folk, perform prayer, recite Qur'an, rest } \\
\text { area, dining place, and at night as a temporary } \\
\text { sleeping area. } \\
\text { Wide open space concept to accommodate } 38 \\
\text { men guests sitting on the floor during special } \\
\text { occasion. }\end{array}$ & $\begin{array}{l}\text { Verandas and Middle area; Full } \\
\text { height wall, window and door; } \\
\text { guest outside might not easy to } \\
\text { view internal dwelling. Full } \\
\text { length window with curtains and } \\
\text { double leaves door in every } \\
\text { space in the dwelling. }\end{array}$ \\
\hline
\end{tabular}




\begin{tabular}{|c|c|c|}
\hline $\begin{array}{l}\text { Semi-Public Space } \\
\text { Middle Area }\end{array}$ & $\begin{array}{l}\text { Place for men, women family member and } \\
\text { relative guest perform prayer; recite Qur'an, } \\
\text { usrah, rest and dining. } \\
\text { Temporary sleep area for men and guest at night. } \\
\text { Restricted movement for guests; the area } \\
\text { adjoining with women domain. }\end{array}$ & $\begin{array}{l}\text { Middle area and Kelek Anak; } \\
\text { door and curtain. } \\
\text { The wall is divided into two } \\
\text { sections which is use timber } \\
\text { plank wall from floor to } 6 \mathrm{ft} \text { high, } \\
\text { followed by } 1 \mathrm{ft} \text { tebuk telus } \\
\text { timber reach ceiling level. }\end{array}$ \\
\hline $\begin{array}{l}\text { Semi-Private Space } \\
\text { (Women family } \\
\text { member and Women } \\
\text { relative guest ) } \\
\text { Kelek Anak, Open } \\
\text { Family Hall and } \\
\text { Dining Hall. }\end{array}$ & $\begin{array}{l}\text { Women do household activities such as sewing, } \\
\text { reading, ironing etc. } \\
\text { All family members having meals at the dining } \\
\text { area. } \\
\text { Hidden from non-mahram eye which emphasis } \\
\text { women privacy. } \\
\text { Not close to men domain. }\end{array}$ & $\begin{array}{l}\text { Middle area and Kelek Anak; } \\
\text { door and curtain. } \\
\text { Kelek Anak and Open Family } \\
\text { Hall; Arch and balustrade to } \\
\text { create spacious space for } \\
\text { women. }\end{array}$ \\
\hline $\begin{array}{l}\text { Women Entrance, } \\
\text { Women Porch and } \\
\text { Open Passage Area }\end{array}$ & $\begin{array}{l}\text { Women entrance; leads to open passage area } \\
\text { and dining. } \\
\text { Women porch as relax area. } \\
\text { Passage area is walking area, link to the nearest } \\
\text { area. }\end{array}$ & $\begin{array}{l}\text { The architectural elements to } \\
\text { divide area and present the } \\
\text { space function. } \\
\text { Women Porch; wall and door to } \\
\text { hide the internal space. }\end{array}$ \\
\hline Kitchen & $\begin{array}{l}\text { Women domain. } \\
\text { Women cooking area. }\end{array}$ & $\begin{array}{l}\text { Dining to Kitchen; arch way as a } \\
\text { divider. }\end{array}$ \\
\hline $\begin{array}{l}\text { Private Space } \\
\text { Room }\end{array}$ & $\begin{array}{l}\text { Room 1: men. } \\
\text { Room2: parents. } \\
\text { Room 3: unmarried woman. } \\
\text { Room function as sleep/rest area, to perform } \\
\text { prayer, change cloth, reading etc. }\end{array}$ & $\begin{array}{l}\text { Full height wall, door, window } \\
\text { and curtain; to create an } \\
\text { enclosed, sacred place and as } \\
\text { private space to protect women } \\
\text { awrah. }\end{array}$ \\
\hline
\end{tabular}

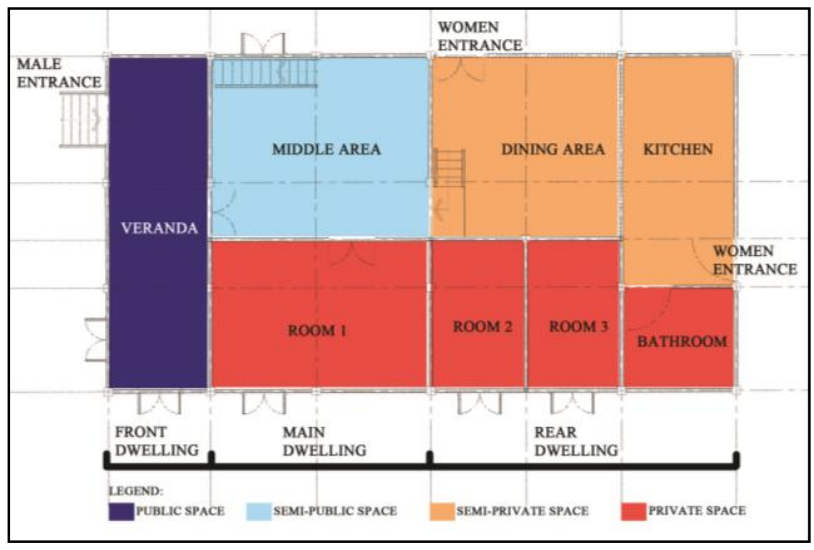

Figure 3: Ordinary village dwelling layout plan

(Source: Survey) 
The total space is 2290.32sq.ft; the dwelling has wide open space to entertain the villages and to accommodate bigger families with nine children that all grew up in this dwelling. Therefore, the dwelling size and layout plan slightly larger than other dwelling in the village. The dwelling facade and interior still remain the family way of life, culture value, religious beliefs, daily activities and privacy value. Table 1 below shows the interrelation between privacy gradient zoning and daily activities.

Fig.3, shows the ordinary village dweller which quite smaller than the headmen dweller. Jored Ali is a representative of the village with $1377.71 \mathrm{sq}$. ft. overall floor plan size. The dwelling form follow to the family needs, number of children and family economy. Usually, the occupants do not deal with the villager and they do not have too huge dwelling it sufficient to accommodate the family members.

Both MD presents the open space concept and where the porch, veranda and middle area can be transformed into a multipurpose area. Multipurpose area place to hold discussions, meetings, sleeping area, family gatherings, cultural events, social events and religious occasions. The interior layout provides clear division between public, semi-public, semi-private and private space. Islam prohibits free mixing of both genders especially between women and non-mahram guests. Table 2, below show the occupant privacy regulates with the interior space planning.

Table 2: The ordinary village MD emphasize on privacy zoning, daily activities and architectural elements.

\begin{tabular}{|c|c|c|}
\hline $\begin{array}{c}\text { Privacy Gradient } \\
\text { Zoning }\end{array}$ & Daily Activities & $\begin{array}{l}\text { Application of Architectural } \\
\text { Elements } \\
\text { (to prevent gazing of guest } \\
\text { toward space) }\end{array}$ \\
\hline $\begin{array}{l}\text { Public Space } \\
\text { (Men family } \\
\text { member and non- } \\
\text { mahram guest) } \\
\text { Men Entrance and } \\
\text { Open Veranda }\end{array}$ & $\begin{array}{l}\text { Main entrance for men and restricted for women. } \\
\text { The open veranda and middle area can be a } \\
\text { multipurpose area within a certain occasion or } \\
\text { time. } \\
\text { Place to entertain guest, discussion area, } \\
\text { rest/relax and temporary sleeping area at night. } \\
\text { Wide open space concept to accommodate } 24 \\
\text { men guests sitting on the floor during special } \\
\text { occasion. }\end{array}$ & $\begin{array}{l}\text { Open veranda; balustrade } \\
\text { only; people outside could } \\
\text { view the area as public } \\
\text { space. }\end{array}$ \\
\hline $\begin{array}{l}\text { Semi-Public Space } \\
\text { Middle Area }\end{array}$ & $\begin{array}{l}\text { Restricted movement for guests; the area } \\
\text { adjoining with women domain. } \\
\text { Place for men, women family member and } \\
\text { relative guest perform prayer; recite Qur'an, } \\
\text { usrah, rest, dining and do household activities. } \\
\text { Temporary sleep area for men at night. }\end{array}$ & $\begin{array}{l}\text { Open veranda to Middle area; } \\
\text { Full height wall, door and } \\
\text { curtain. } \\
\text { It also has } 6 \mathrm{ft} \text { high window } \\
\text { and curtains at main dwelling. }\end{array}$ \\
\hline $\begin{array}{l}\text { Semi-Private } \\
\text { Space } \\
\text { (Women family } \\
\text { member and } \\
\text { Women relative } \\
\text { guest) }\end{array}$ & $\begin{array}{l}\text { Women domain and do their household activities. } \\
\text { All family members having meals in the dining } \\
\text { area. } \\
\text { Women cook in the kitchen. }\end{array}$ & $\begin{array}{l}\text { Full height wall, arch way and } \\
\text { curtain; to divide the space }\end{array}$ \\
\hline
\end{tabular}




\begin{tabular}{|l|l|l|}
\hline $\begin{array}{l}\text { Women Entrance, } \\
\text { Dining area and } \\
\text { Kitchen }\end{array}$ & & \\
\hline Private Space & $\begin{array}{l}\text { Room 1: men. } \\
\text { Room2: parents. }\end{array}$ & $\begin{array}{l}\text { Room 3: unmarried woman. } \\
\text { Room function as sleep/rest area, to perform } \\
\text { various activities. }\end{array}$ \\
\hline
\end{tabular}

(Source: Mortada (2003), Abdul-Rahim (2008) and Omer (2011)

There is a clear difference not only in the hierarchy structure and function space of the dwelling, the space differentiates by the walls, the floor levels and the number of the entrance (Masri, 2013). The men and women family member may use the entire space in the dwelling, but they respect and understand the concept of domain, the need of privacy and gender separation. Non-mahram guests were invited only at public and semi-public space in order to maintain the women privacy that located at the back of the dwelling. Private space is considering as a sacred place and hidden from non-mahram eye.

In Islamic teaching, there is a need to the separate bedroom when they reach 7 years old. Therefore, the room separation between parents, children or adult women and men is needed in order to prevent un-ethical behavior occur in the family. The priority room is for unmarried women, if there have more room parents and children or adult men are able to use the room. In certain cases, the extra room will be used by relative women. The MD applied the architectural element such as door, window, arch way, opening, balustrade, floor level and curtain due to the visual privacy.

Window with curtain will be used in every area and function to view the environment outside. The curtain is made to maintain the dweller privacy and also to avoid the neighbor's eye to overlooking internal space. Door is required between public, semi-public, semi-private and private space is to ensure the security, visual privacy of the dweller.

Both case study researches demonstrate part of the Malay culture in accordance with Islamic teaching toward the application in daily activity, privacy gradient zoning, privacy requirement, visual privacy, architectural element and gender segregation in spatial organization of MD. All details could be seen in fig.2, table 1, fig. 3 and table 2 .

\subsection{Conclusion}

Fig.4 demonstrates the similarities show the differences between both MD towards the privacy gradient zoning, daily activities and application of architectural elements.

In Fig.5 show the finding that provides the Islamic concept of privacy in the interior of MD. Both selected MTD apply all five elements focus on spatial planning and architectural elements which to prevent the visual intrusion towards women privacy.

The Islamic concept of privacy can be used in both types of floor size, whether the dwelling space is big or small. Mortada (2003), Abdul-Rahim (2008) and Omer (2011) state 
that the Islamic privacy concept and laws need to function properly in order to produce wellbeing, good manner and the behavior of Muslim community. This is to prevent from any intrusion of privacy life amongst Muslim family also to afford protection for the family privacy that will achieve level of privacy. The in-depth interview with occupant reveals that religious beliefs, cultural norms and daily activities of the Malays remain to be important aspects in regulating the privacy in the families.

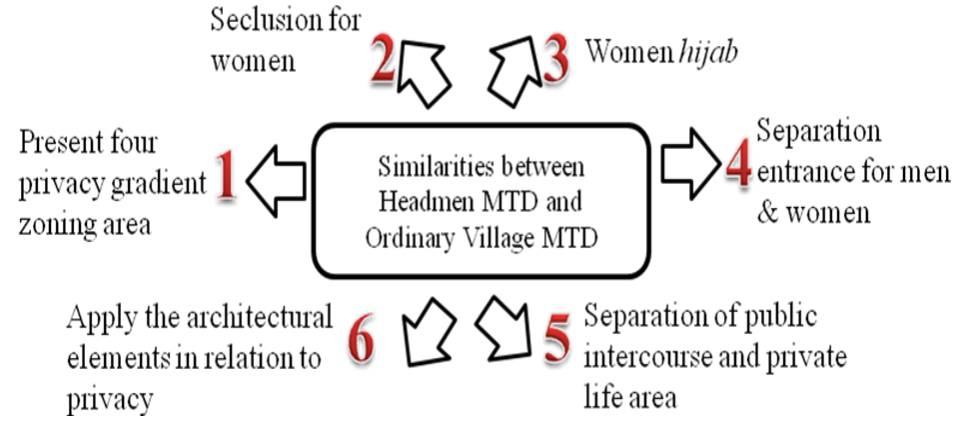

Figure 4: The similarities between both MD towards the concept of Islamic privacy (Source: Mortada (2003), Abdul-Rahim (2008) and Omer (2011)

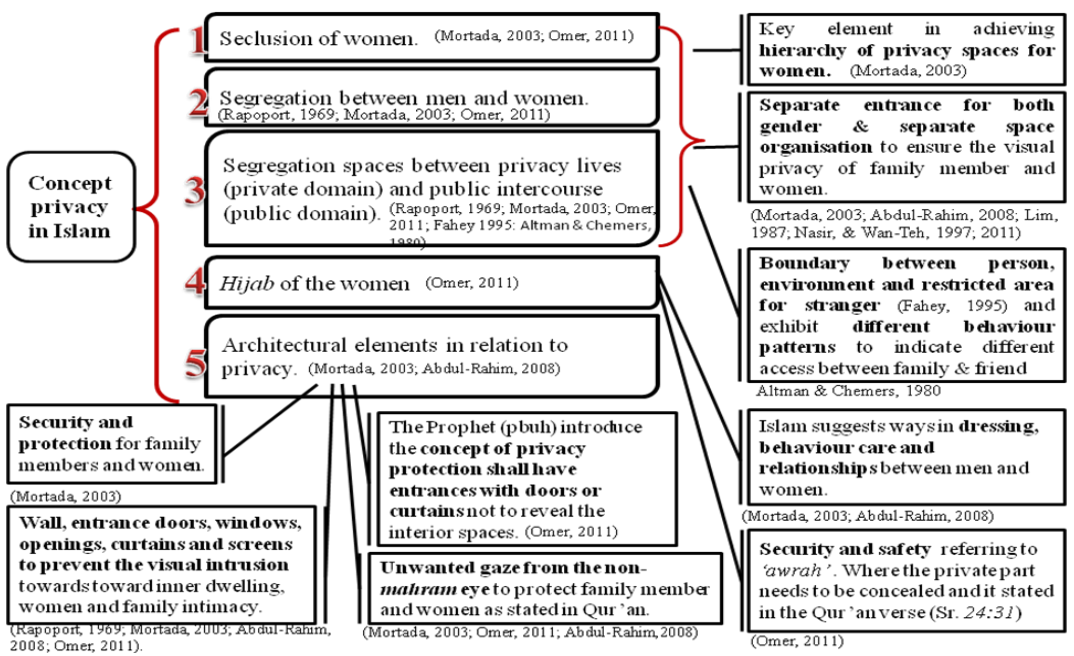

Figure 5: Concept privacy in Islam

(Source: Mortada (2003), Abdul-Rahim (2008) and Omer (2011)

The religious beliefs would enhance the quality of life in space planning, privacy value, educate the occupants and prevent unethical act. The interior space planning is divided 
followed to religious and cultural beliefs (Rapoport, 1969) of the Malays. Both dwelling has different size of layout plan and form. The form of the headmen dwelling influence from the west, however both MD represent the Malay culture. The size of dwelling layout and placement of women is referring to the type of family structure followed accordingly to the culture, religious belief, and the way of life (Rapoport, 1969) also needs of privacy.

The understanding of Muslim way of life, gender segregation, woman domain, architectural elements and visual privacy have to be taken into considerations in designing Muslim dwelling in future. Moreover, it will result a positive environment to controlling the social interaction in Muslim family that involve non-mahram guests. It is recommended to implement the Islamic concept of privacy shows in fig.5, in order to achieve the acceptable levels of privacy in Muslim family. The findings will be used to draw up design recommendations for future layout plans of the modern dwellings in Melaka. Further research, should be study on acoustics privacy.

\section{Acknowledgement}

This research cannot be accomplished without the assistance and inspiration of Assoc. Prof. Dr. Anuar Talib towards research issue and methodology. I would like to express my sincere gratitude to the International Islamic University Malaysia for funding my research and Ministry of Higher Learning for funding my conference

\section{References}

Al-Ahmadi, A. R. (2006). Petua Membina rumah Melayu: Dari Sudut Etnis Antropologi. Kuala Lumpur: Perpustakaan Negara Malaysia.

Altman, I. (1975). The Social Environment and Behavior; Privacy, Personal Space, Territory and Crowding. Monterey, California: Brooks / Cole Publishing Company.

Altman, I., \& Chemers, M. M. (1984). Culture and Environment (basic concepts in environment and behavior series). New York: Cambridge University Press.

Altman, I., Vinsel, A., \& Brown, B. B. (1981). Dialectic Conceptions in Social Psychology: An Application and Privacy Regulation. Advances in Experimental Social Psychology , 14, 107-157.

Abdul Rahim, Z., \& Hashim, A. H. (2012). Behavioral Adaptation of Malay Families and Housing Modification of Terrace Houses in Malaysia. cE-Bs, Architecture, 1-14.

Rahim, A. A. (2008). Housing from the Islamic Perspective. Selangor: IIUM Press,.

Creswell, J. W. (2012). Educational Research, Planning, Conducting and Evaluating Quantitative and Qualitative Research; Fourth Edition. Pearson Education, Inc.

Creswell, J. W. (2009). Research Design, Qualitative, Quantitative and Mixed Methods Approaches; Third Edition. SAGE Publications. 
Mohd Razali, N.H., \& Talib, A. / Asian Journal of Behavioural Studies (AjBeS), 3(11) May / Jun 2018 (p.157-167)

Fahey, T. (1995). Privacy and Family: Conceptual and Empirical Reflections. Sociology Journal of the British Sociology Association. , 24 (4), 687-702.

Hall, E. T. (1990). The Hidden Dimension. New York: Anchor Books Edition.

Lim, J. Y. (1987). The Malay House; Rediscovering Malaysia's Indigenous Shelter System. Pulau Pinang: Institut Masyarakat.

Mortada, H. (2003). Traditional Islamic Principles of Built Environment. New York: Routledge Curzon.

Nasir, A.H., \& Wan-The,W.H. (1997). The Traditional Malay House. Shah Alam: Fajar Bakti.

Nasir, A.H., \& Wan-The,W.H. (2011). The Traditional Malay House.Kuala Lumpur: Institut Terjemahan dan Buku Malaysia.

Newell, P. B. (1995). Perspectives on Privacy. Journal of Environmental Psychology , 15, 87-104.

Omer, S. (2011). Housing Lessons from the Life of Prophet Muhammad (pbuh): The Subject of Privacy. Retrieved April 23, 2012, from medina.net: http://www.medinanet.org/home/10-housing/178-housing-lessons-from-the-life-ofprophet-muhammad-pbuh-the-subject-of-p

Omer, S. (2010). Islam and Housing. Gombak, Kuala Lumpur: A. S. Noordeen.

Rapoport, A. (1969). House Form and Culture. Eaglewood Cliffs, N.J, U.S.A: Prentice-Hall, Inc.

Rapoport, A. (2007). Some Further Thoughts on Culture and Environment. Archnet-IJAR, International Journal of Architectural Research, March 2008. 2(1). 16-39. 